\title{
The direct solid method of geometry analysis of the globoidal worm gear with the rotary teeth
}

\author{
Bezpośrednia bryłowa metoda analizy śladu styku \\ globoidalnej przekładni ślimakowej z obrotowymi zębami
}

PATRYCJA EWA JAGIEKOWICZ*

DOI: https://doi.org/10.17814/mechanik.2018.2.33

The tooth contact analysis (TCA) in the wheel rotation function of the globoidal worm gear with rotary teeth was presented. To determine the contact in CAD system, the direct solid method of geometry analysis was used. In the gear the globoidal worm gear was used, and the classical worm wheel was replaced by the wheel with rotary teeth in the shape of the frustum of cone.

KEYWORDS: globoidal worm gear, globoidal worm, tooth contact analysis, CAD systems

Przedstawiono analizę śladu styku w funkcji obrotu kół globoidalnej przekładni ślimakowej z obrotowymi zębami. W celu określenia śladu styku w systemie CAD wykorzystano bezpośrednią bryłową metodę analizy geometrii. W przekładni zastosowano ślimak globoidalny, a klasyczną ślimacznicę zastapiono kołem z obrotowymi zębami w kształcie ściętych stożków. SŁOWA KLUCZOWE: globoidalna przekładnia ślimakowa, ślimak globoidalny, analiza śladu styku, środowisko CAD

Globoid worm gears are composed of a helical or torus wormwheel and a globoid worm, whose longitudinal cross-section profile closely adheres to the wormwheel. In the cylindrical worm gear, the worm teeth are cut on the cylinder, and in the globoid gear on the concave rotating surface, where the pitch radius of the worm is equal to the pitch radius of the cooperating worm. Comparatively to helical worm gear, the globoid worm gears are characterized by lower operating wear and greater efficiency [1, $2,8,9]$. More advantageous is the position of the contact line and the simultaneous cooperation of more number of teeth - multipair tooth contact [1, 2, 8, 9]. In the described gear, the wheel of the wormwheel is positioned towards the worm at an angle $90^{\circ}$. Due to the axis twisting between the worm coil and the wormwheel teeth, there are high rubbing speeds $[4,5]$. At the higher loads there is a seizure of the teeth, because the rubbing speed increases as the raising angle of the worm coil line increases. The disadvantage of such gears is also poor efficiency, and consequently - strong warming and cooling necessity. The disadvantages include technological difficulties and high sensitivity to the accuracy of the making these gears [9]. Worm gears are used in cases where high gear ratios are required, and often also axis changes. In the point of contact analysis, the correct description of the cooperating surfaces, i.e. the wormwheel roll and the worm coil is important primarily. This description mainly depends on the

* Dr inż. Patrycja Ewa Jagiełowicz (pejagielowicz@prz.edu.pl) - Katedra Konstrukcji Maszyn, Wydział Budowy Maszyn i Lotnictwa Politechniki Rzeszowskiej case of machining - the form of the tool working surface and kinematic of the machining process of the parameters. However, in the description, the gear teeth of a cooperating wheel is not considered. The surfaces of the two wheels should be shaped and interlocked in the way to let the gear fulfill a function as a mechanism that transmits rotary motion. The gears, that theoretically transmit the rotary motion accurately according to a given function are called conjugated or precision ones. Most precision gears have a linear tooth contact. Linear tooth contact gear is very sensitive to mounting errors, such as angle error between wheel axles, axle displacement error, wheel axle displacement error [9]. In hypothetical gear, working without the load, the temporary contact trace is a point or line. On the other hand, in a real gear, it is a surface of the area around the hypothetical point or line of cooperating teeth that contact with themselves. That is because in practice it is almost impossible to obtain the perfectly precise tooth surfaces. Hence, the approximate gears with point contact of the teeth are used. The tooth flanks of these gears are not mutually hobbed, so they adapt to real working conditions better, they are more resistant to assembly errors and can be manufactured in a variety, highly efficient methods. Gears that have a point shape of contact trace are less durable than gears with linear tooth contact. In the design of the approximate gear, the geometric parameters of the tool and the setting parameters of the machine should also be determined so that the relevant engagement quality indicators are met. In the interlocking of each gear, the correct contact between the cooperating teeth is very important. In the worm gears the contact is linear and the shape of the contact line depends on many factors. One of them is the worm tooth profile that basically influences the carrying capacity of the gear [3]. It should be emphasized that the description of interlocking geometry of the worm gears is not easy. Especially it is complicated in the description of the cone-derivative profile of the worm. Science papers in open literature have been concentrated on the extensive investigations on precision manufacturing and product design in that empirical studies have been published $[6,7,10]$.

\section{Methods}

To reduce the sliding friction, the new type of wormwheel was created $[11,12]$. The wormwheel teeth have a shape of truncated cone and are rotatably mounted in the rolling or sliding bearings (fig. 1). The conical shape of the rotating tooth allows to minimize slipping of the cooperating surfaces of the teeth [5]. 


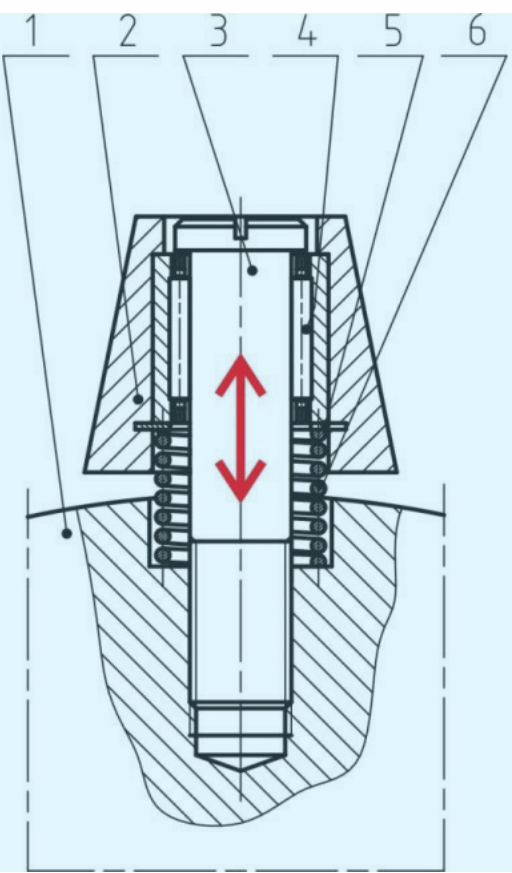

Fig. 1. Exemplary structural solution of the teeth clamp: 1 - worm body, 2 - the rotary teeth, 3 - mandrel, 4 - rolling bearing, 5 - washer, 6 - push spring

Figure 2 shows the scheme of the globoidal worm gear with the rotary teeth and established parameters:

a - axis distance,

$b$ - half the pitch-surface generator of roller,

$l$ - half the thickness of roller on the pitch diameter,

$r$ - wormwheel pitch radius,

$r_{1}$ - worm pitch radius,

$r_{1 \mathrm{a}}-$ worm addendum radius,

$r_{1 \mathrm{f}}-$ worm dedendum radius,

$\alpha_{1}$ - worm normal pressure angle

$\alpha_{2}$ - roller normal pressure angle,

$\gamma_{1}$ - initial mesh angle,

$\gamma_{2}$ - terminal mesh angle,

$\varphi$ - auxiliary angle,

$\omega_{1}-$ worm angular velocity,

$\omega_{2}-$ wormwheel angular velocity.

The worm normal pressure angle depends on the roller normal pressure angle and on the number of wormwhee teeth. The worm normal pressure angle is given by the formula:

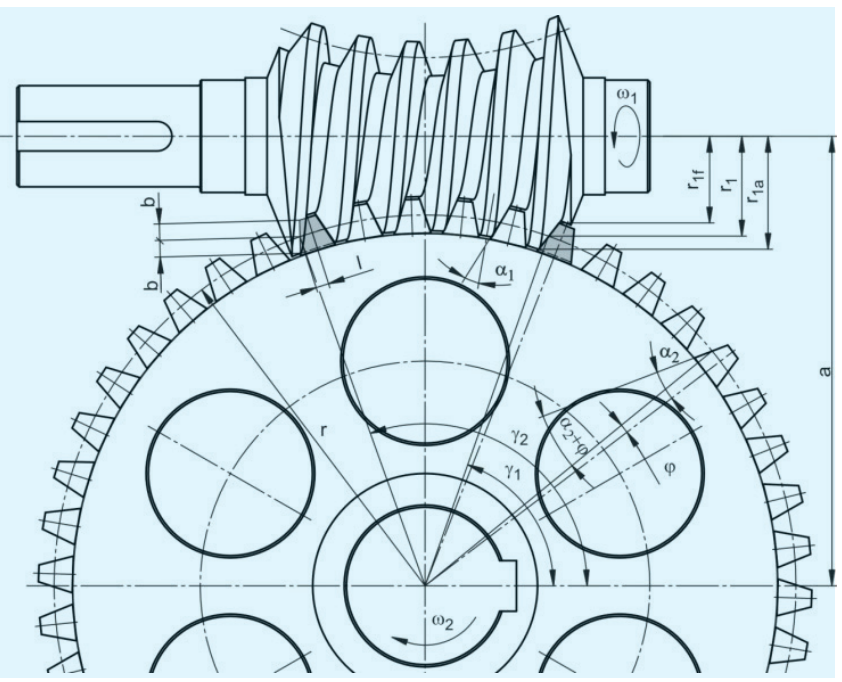

Fig. 2. Scheme of the globoidal worm gear with the rotary teeth

$$
\alpha_{1}=\frac{360}{2 \cdot z_{2}}+\alpha_{2}
$$

where $z_{2}-$ number of wormwheel teeth.

The mating of teeth is considered in the range of $\gamma$ angle from $\gamma_{1}$ to $\gamma_{1}$. There are few specialized applications to generate this type of gear, so it is necessary to rely on general purpose CAD systems. Due to the capabilities of the available programs, the work was carried out on two systems - AutoCAD and CATIA, whereas the contact trace analysis was carried on in AutoCAD and Inventor programmes. The modelled globoid worm gear was shown in a simplified way in the fig. 3. The worm (1) drives the wormwheel (2) whose teeth (3) can rotate around their own axis.

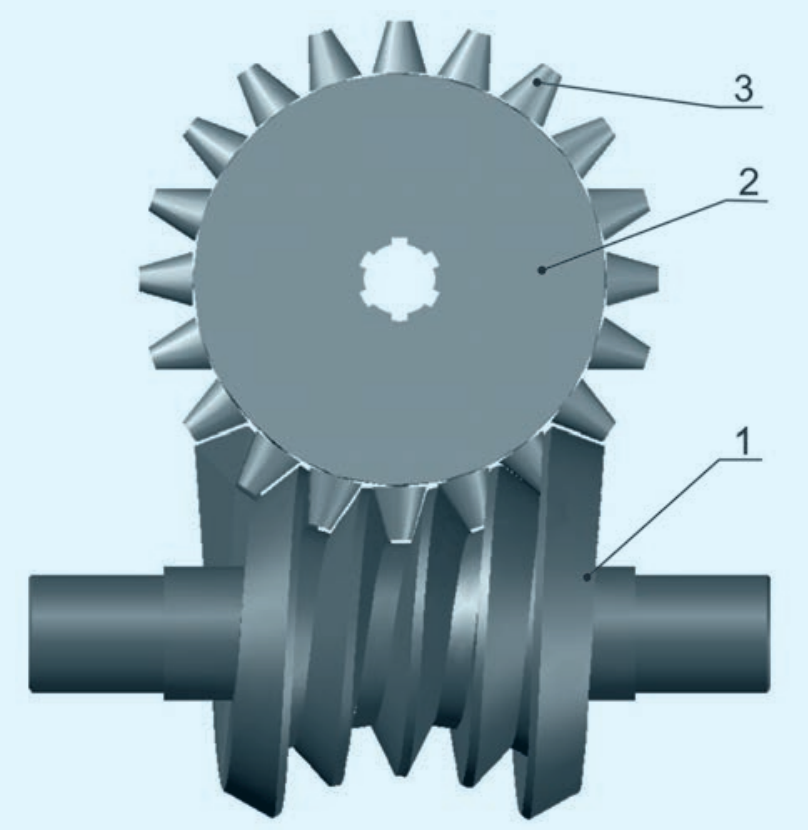

Fig. 3. The worm and worm wheel of the globoidal worm gear, with the rotary teeth: 1 - worm, 2 - worm wheel body, 3 - rotary tooth

The first step is to assume and determine the basic gear parameters: the number of the teeth and the wormwheel, the tooth module, the distance of the axis of gears, the angle of the tooth profile, the reference diameter of the worm, the reference diameter of the worm wheel etc. The table shows the worm gear parameters. The geometrical dimensions of the rotating tooth are adjusted in such a way that the forces between them and the flank of the worm coil assure contact on the demanded number of teeth. In addition, the geometry must be selected

TABLE. The globoid worm gear data

\begin{tabular}{|l|c|}
\hline \multicolumn{1}{|c|}{ Parameter } & Amount \\
\hline Number of worm coils $z_{1}$ & 1 \\
\hline Number of wormwheel teeth $z_{2}$ & 20 \\
\hline Transmission ratio $i$ & 20 \\
\hline Normal module $m, \mathrm{~mm}$ & 7 \\
\hline Circumferential backlash $I_{\mathrm{o} 2}, \mathrm{~mm}$ & 0.28 \\
\hline Clearance $I_{\text {w2 }}, \mathrm{mm}$ & 1.40 \\
\hline Axis distance $a, \mathrm{~mm}$ & 105 \\
\hline
\end{tabular}


so that the roller surface works only on one side with the worm coil surface, and on the other side the backlash $c_{0}$ should be left because the relative movement of the rotating tooth surface and the worm has opposite direction there.

During the operation of the gear, the wormwheel teeth mesh tangentially to the lateral surface of the worm coils. Compression springs, which in the worm body the rollers are mounted on, flex. In that, the there is a non-backlash work, when a clamp of the conical surface of rotary tooth to worm operating surface is assumed. Because at the same time there should be several teeth in the area of cooperation, due to the accuracy of realisation and montage, there would be a situation, when the contact did not occur on all teeth. To prevent this situation, the teeth have the possibility of axial movement, thanks to the assumed play. In classical gear, the backlash can also arise during its long life. This solution also allows you to cut out this backlash. Additionally, due to the accuracy of the realisation, in the normal gear, there are fewer teeth in the meshing gear than it results from the design assumptions. In the presented solution, in the area of cooperation all the teeth always work - there is a multi-pair tooth contact, so the forces distribution on the working teeth is more even. The great advantage of this transmission is the greater efficiency resulting from the conversion of sliding friction to rolling friction by the use of bearings.

\section{Results}

To determine the contact trace in CAD system, the direct solid method of analysis of the geometry was used. It is needed to adjust the worm and wormwheel mutually at first. This setting is a result of the theoretical setting of a rotary tooth of one wheel in the center of the worm keyway, with using the calculated axial distance and the axis crossing angle. Collaborating teeth of the wormwheel roller and the worm coils, penetrate into a $\delta$ depth, corresponding to the mutual hollow obtained in the FEM

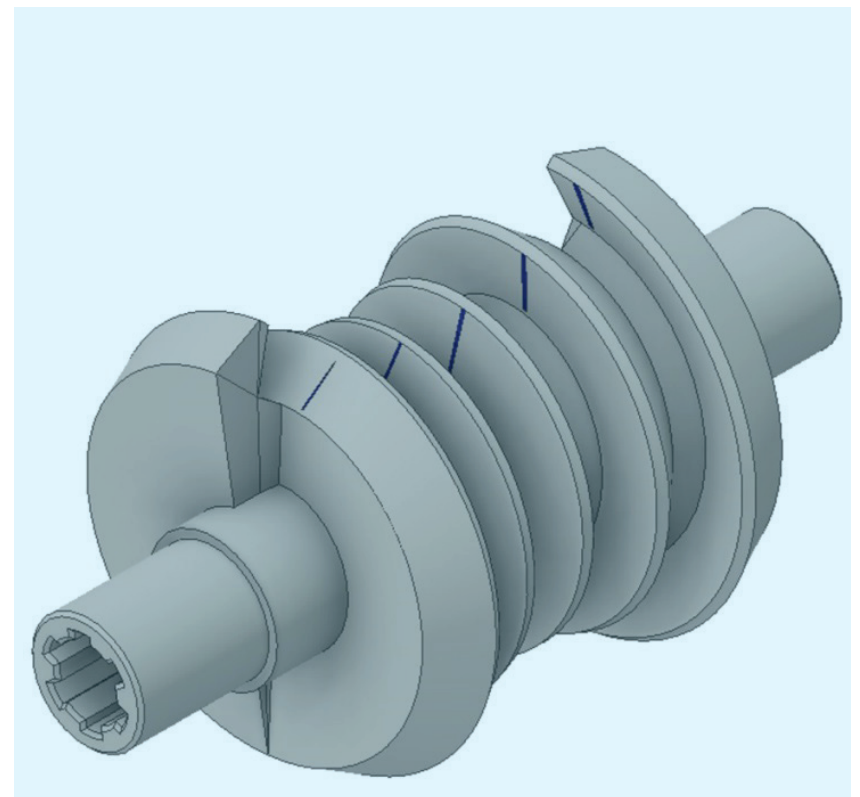

Fig. 4. Temporary tooth contact - the worm

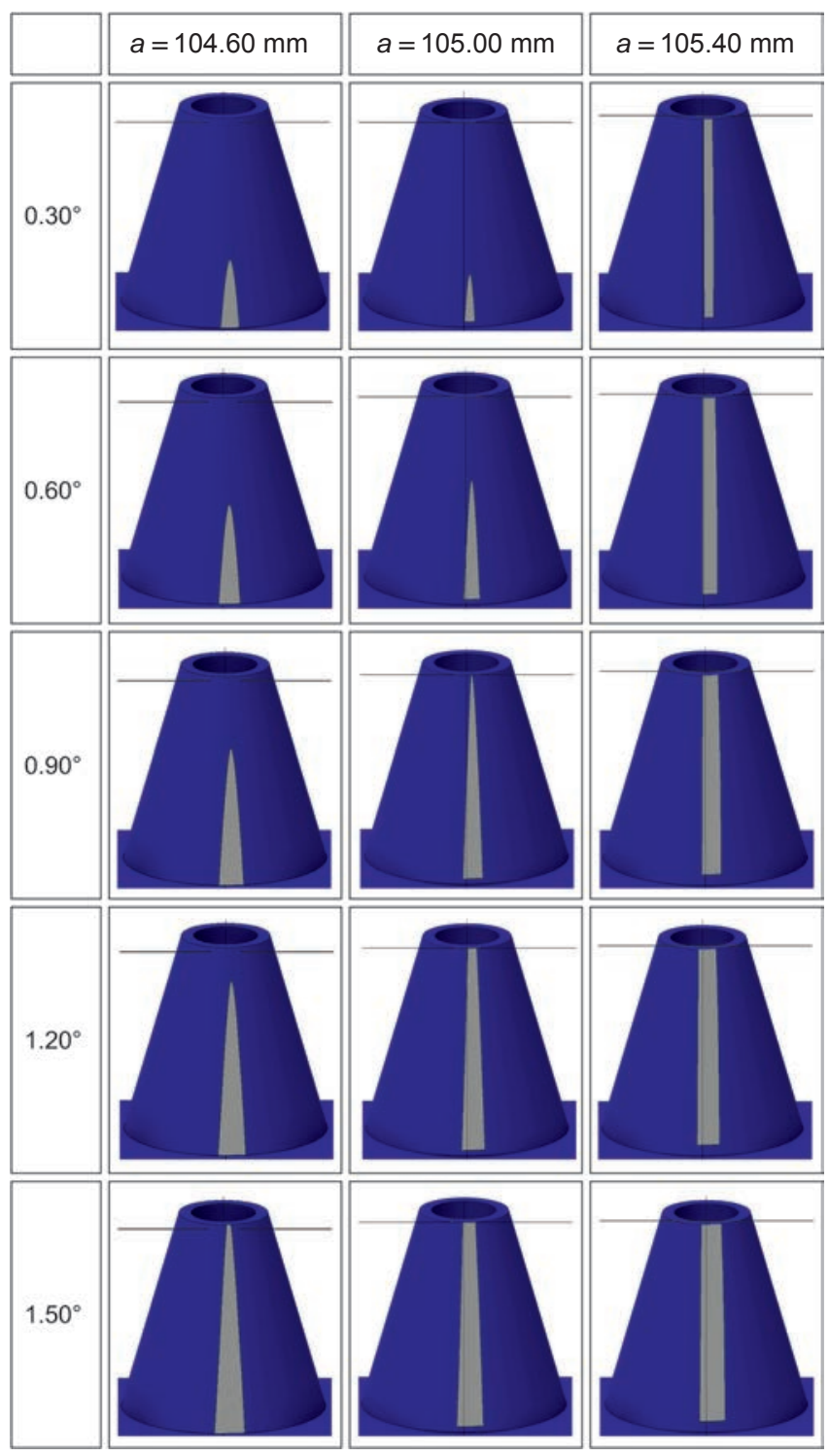

Fig. 5. Temporary tooth contact for different hollow values - the wormwheel

analysis. A temporary contact trace for a given relative setting is obtained by performing a regularized operation of Boolean product of the worm and wormwheel models. Then the work of transmission was simulated by turning one of the gear wheels by the angles resulting from the theoretical transmission ratio. Figure 4 shows the setting of the worm contact trace on the worm for $0.30^{\circ}$ and distance $a=105 \mathrm{~mm}$.

Figure 5 shows the resulted contact trace for different hollow values - one of the tooth contact is shown here.

The size and setting of meshing tooth contact surface depend on the worm rotation angle and thus the set value of the solid hollow towards each other. The obtained contact trace surfaces in the worm rotation function for slice of worm are illustrated in fig. 6 . The setting and size of the contact track surface are affected by the axis distance. Figure 7 shows the results obtained for three axial distances: $104.60 \mathrm{~mm}, 105 \mathrm{~mm}$, and $105.40 \mathrm{~mm}$ in the worm rotation function.

The size of the contact trace surface does not change linearly. This is due to the geometry of the worm - the tooth flank of the globoid worm coil is not straighttraced. At the moment there may be several pairs of surfaces in contact, therefore the sum of temporary contact trace equals the total temporary tooth contact. 


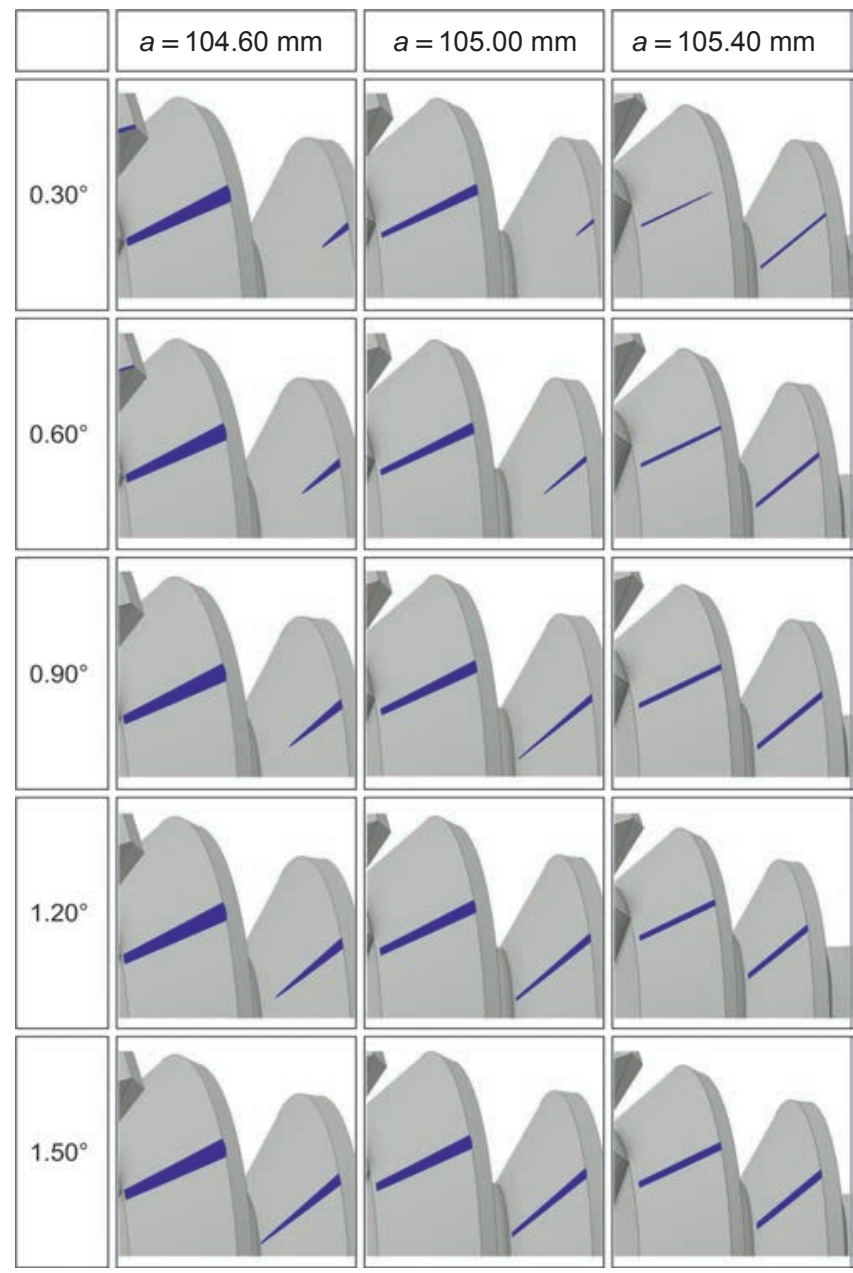

Fig. 6. Temporary tooth contact for different hollow values - the worm

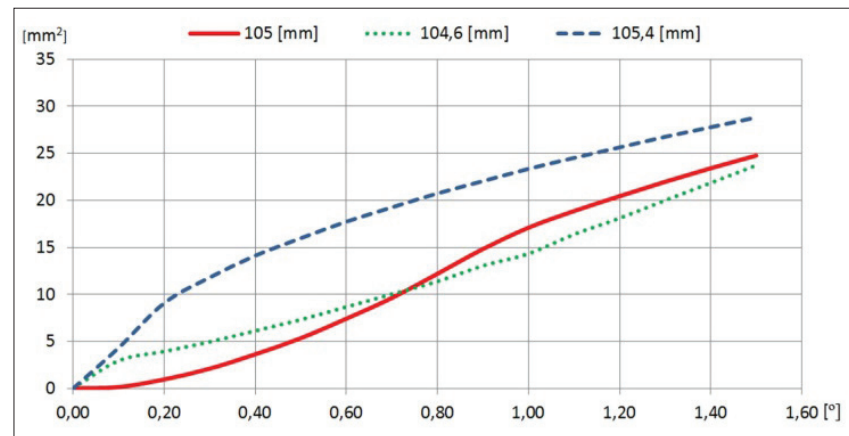

Fig. 7. Contact trace surface in the worm rotation function for three axis distance values

\section{Discussion}

The contact track in the worm gear model is conventional because it depends on the assumed depth of mutual hollow of the teeth of both wheels. The theoretical contact between the surfaces of the cooperating rolls of the wormwheels and the worm coil proceeds along the element of a truncated cone. The contact trace is displaced towards the lower base of the truncated cone. Considering the deformation capability of the cooperating flanks of the teeth, a certain surface is always obtained. The size of the contact trace surface does not change linearly because the lateral surfaces of the globoid worm coil are not straighttraced. The distance changing of the worm and wormwheel axis has a significant impact on the emerging contact trace. For lower values, a larger area of the tooth contact is resulted. At the moment there may be several pairs of surfaces in contact, therefore the sum of temporary contact trace equals the total temporary contact trace. The resulted contact trace provides information on the subject of the correctness of the gear modeling and its operation. The moment of contact is an approximation of the actual trace, because the vibration phenomena, thermal deformation, tooth deflection are not considered. Analysis of the contact trace simultaneously showed that the design assumptions and model realisation were correct. Knowing the phenomena as contact trace or the combined contact track allows to pre-evaluate the correctness of gear operation. Analysis of contact trace changes provides an estimative assessment of the gearing kinematic accuracy and the gearing capacity. The use of geometric analysis, and among others the determining of total contact trace changes, let eliminate the geometrically mistaken construction on the phase of gears designing. This contributes to get manufacturing costs lower, especially for wheels with unusual teeth profiles. Particularly important for the force of the worm gear is to provide a proper cooperating trace during assembly. A common mistake in this operation is the asymmetrical positioning of the wormwheel towards the worm. Moreover, under the influence of the transmitted load, as a result of gear elements bending, the cooperation trace displaces. The result of the displacement is both the lubricious key decline, and surface pressureses accumulation. This is a frequent cause of fatigue wear, which can pass or accure during operation leading to premature wear the gear off. It is recommended to set the initial cooperation trace so that only under the influence of the load to be on the side of the mesh.

\section{Acknowledgments}

The work was done within DS/M.MK.17.006 deal to do the research to develop young scientists and doctoral students.

\section{REFERENCES}

1. Kornberger Z. „Przekładnie ślimakowe”. Warszawa: WNT, 1973.

2. Marciniak T. „Technologia przekładni ślimakowych”. Łódź: Wydawnictwo Naukowe Instytutu Technologii Eksploatacyjnej PIB, 2013

3. Jagiełowicz P.E. „Modelowanie powierzchni globoidalnych w środowisku CAD". Mechanik. 2 (2015).

4. Skoczylas L. „Prędkość poślizgu w zazębieniu przekładni ślimakowej”. Archiwum Technologii Maszyn i Automatyzacji. 27, 2 (2007).

5. Sobolak M., Jagiełowicz P.E. „Dobór kata zarysu zęba obrotowego w globoidalnej przekładni rolkowej”. Mechanik. 5-6 (2014): s. 442-443.

6. Krolczyk G., Legutko S., Nieslony P., Gajek M. „Study of the surface integrity microhardness of austenitic stainless steel after turning". Tehnički Vjesnik - Technical Gazette. 21, 6 (2014): s. 1307-1311.

7. Krolczyk G., Legutko S., Stoić A. „Influence of cutting parameters and conditions onto surface hardness of duplex stainless steel after turning process". Tehnički Vjesnik - Technical Gazette. 20, 6 (2013): s. $1077-1080$.

8. Lagutin S., Gudov E., Fedotov B. „Manufacturing and load rating of modified globoid gears". Balkan Journal of Mechanical Transmis sions. 1 (2011): s. 45-53.

9. Litvin F.L., Sheveleva G.I., Vecchiato D. „Modified approach for tooth contact analysis of gear drives and automatic determination of guess values". Computer Methods in Applied Mechanics and Engineering. 194 (2005): s. 2927-2946.

10. Nieslony P., Krolczyk G.M., Zak K., Maruda R.W., Legutko S. „Comparative assessment of the mechanical and electromagnetic surfaces of explosively clad Ti-steel plates after drilling process". Precision Engineering. 47 (2017): s. 104-110.

11. Sobolak M., Jagiełowicz P.E. Patent for invention No. P.407800 entitled: „Roller backlash-free gear drive, especially globoid worm gear”. 04.04.2014, NP/144/2014.

11. Sobolak M., Jagiełowicz P.E. Patent na wynalazek nr P.407800: „Przekładnia zębata rolkowa bezluzowa, zwłaszcza ślimakowa globoidalna". 04.04.2014, NP/144/2014.

12. Sobolak M., Jagiełowicz P.E. Patent na wynalazek nr P.407801: „Przekładnia zębata rolkowa bezluzowa, zwłaszcza ślimakowa globoidalna". 04.04.2014, NP/145/2014. 